\title{
Statistical Evaluation of Seasonal Effects to Income, Sales and Work- Ocupation of Farmers, the Apples Case in Prizren and Korça Regions
}

\author{
PhD. Eriona Deda \\ Faculty of Economics and Agribusiness, \\ Agricultural University of Tirana
}

Doi: 10.2478/ajis-2018-0032

\begin{abstract}
This paper is focused on the statistical assessment of seasonal effects on farmers' income, their workocupation in farm, and sales of apple products. In focus of this study we have taken two regions Prizren and Korça. By making a comparing between Albania and Kosovo, with regard to significance of the model of seasonal effects for apples. In this paper we have used several statistical and econometric methods to evaluate the seasonal effects on economic phenomena taken in the study. We have used the variation indicators to show the distribution of the observed phenomenon. We also have used dummy variable models. Dummy variables are often used in time series analysis, in seasonal and qualitative analysis of applied data. Each dummy variable is set to 1 if the point of datas is received from a specified season and otherwise 0 . To evaluate the seasonal effects in a time series through 1dummy variables, we need to use four dummy variables, one for each quarter, or three dummy variables and a constant. These variables use them as inputs or factors in a regression model. In our paper, we have categorized sales, for apples in 5 different periods. To estimate the magnitude of seasonal effects and to test their significansy are used four dami variables. The purpose of this paper is to show whether the pattern of seasonal effects for apples is significant.
\end{abstract}

Keywords: seasonal effect, model significance, variation indicators, dummy variables

\section{Introduction}

In this paper we have used several statistical and econometric models to estimate seasonal effects in the economic phenomena taken in this study:

We are based on variation indicators to show the distribution of the observed phenomenon.

We have collected data on farmers who cultivate apples. For two regions of Korça and Prizren, we have collected data to analyze the impact of seasonal effects on the economic phenomena taken in the study. We have collected the data through surveys and questionnaires for the two regions studied.

Also are used the dummy variables model to estimate the magnitude of seasonal effects and to test their significance.

\section{The Research Problem}

The research problem is to estimate the magnitude of seasonal effects and to test their significance using DUMMY variables:

\footnotetext{
${ }^{1}$ Osmani,M (2010), Econometric analysis with dummy variable (pp.129-130) Tirane, Albania 2010
} 
We have categorized the sales for these different periods.

DUMMY Sales2 $=1$, for September-October period, 0 for other periods.

DUMMY Sales $3=1$, for November to December period, 0 for other periods.

DUMMY Sales $4=1$, for January-February period, 0 for other periods.

DUMMY Sales $5=1$ for March to June period, 0 for other periods. variables.

To estimate the magnitude of seasonal effects and to test their signi ficance use 4 dummy

Another important problem is determination of influence of external factors on the economic phenomena taken in the studies.

Which is determined through the ${ }^{2}$ coefficient of variation that is a relative indicator that expresses the magnitude of the ratio between the standard deviation and the arithmetic mean of the mass phenomenon.

As smaller is the coefficient of variation more homogeneous are data of the quantity of the phenomenon, so the influence of external factors is in min and vice versa.

\section{Methodology}

Primary data have been collected through surveys and questionnaires about farmers who cultivate apples in Korca and Prizren regions. In total, we surveyed 100 farmers cultivating apples in the Korça region and 30 farmers surveyed who cultivate apples in Prizren region based on interviews.

The purpose of data collection through these surveys is to highlight the impact of seasonal effects on these economic phenomena, farmer's income, sales and employment of farmers in apple cultivation over a year and quarterly, making a comparison between two Regions, Korça and Prizren.

Also, purpose of the primary data collection is to determine in which quarters are more expressed seasonal effects in regions taken in the study.

Secondary data. Regarding the collection of secondary data, we have collected considerable information from Statistics module and from applied Econometrics. Also, we have collected considerable information from the internet, and we have used Eviews 3 program to analyze data through statistical and econometric models to test significance of the seasonal effects on economic phenomena taken in the study.

Regarding the methods we have used, this paper also includes descriptive and analytical methods.

We are based on variation indicators to show the distribution of the observed phenomenon. The coefficient of variation is a relative indicator that expresses magnitude of the ratio between standard deviation and arithmetic mean of the mass phenomenon.

As smaller is coefficient of variation more homogeneous are the data of quantity of the phenomenon, So the influence of the external factors is in min and vice versa.

We also have used dummy variables model to estimate magnitude of seasonal effects and to test the significance of seasonal effects.

regard to sample taken in the study, it consists of 130 farmers:

1. In Prizren region, we have received 30 questionnaires (polls) from some farmers in Prizren that deal with apple cultivation in relation to seasonal differentiations in the economic phenomena taken in the study: Income, work occupation of farmers in farm , and sales.

2. In Korça region, we have received 100 questionnaires (surveys) from some farmers dealing with apple cultivation in relation to seasonal differentiations in the economic phenomena taken in the study: Income, work-occupation, and sales.

As far as the sample selection method is concerned, we have used accidental selection technique.

Regarding the questionnaire: We have paid particular attention to: question sorting, identifying independent and dependent variables, contacting farmers, collecting data, and evaluating of

\footnotetext{
${ }^{2}$ Osmani, M. (2004). Coefficient of variation (pp.99-101). Tirana, Albania: GEER, 2004.
} 
questions.

Types of questions are in a closed form, which provide various tabular and sorted options where the interviewer can respond by selecting or marking the appropriate option.

\section{Analysis and Findings}

\subsection{Sale apples Korça}

For apples sale in Korça region we have evaluated the following model:

Dependent Variable: Sale

Method: Least Squares

Sample: 1500

Included observations: 500

\begin{tabular}{lllll}
\hline \hline Variable & Coefficient & Std. Error & t-Statistic & Prob. \\
\hline \hline C & 2.350000 & 1.136735 & 2.067324 & 0.0392 \\
DUMMY S2 & 78.10000 & 1.607586 & 48.58215 & 0.0000 \\
DUMMY S3 & 6.250000 & 1.607586 & 3.887816 & 0.0001 \\
DUMMY S4 & -1.900000 & 1.607586 & -1.181896 & 0.2378 \\
DUMMY S5 & -0.550000 & 1.607586 & -0.342128 & 0.7324 \\
\hline \hline R-squared & 0.882437 & Mean dependent var & 18.73000 \\
Adjusted R-squared & 0.881487 & S.D. dependent var & 33.01996 \\
S.E. of regression & 11.36735 & Akaike info criterion & 7.709317 \\
Sum squared resid & 63962.25 & Schwarz criterion & 7.751463 \\
Log likelihood & -1922.329 & F-statistic & 928.8784 \\
Durbin-Watson stat & 2.348607 & Prob(F-statistic) & 0.000000 \\
\hline \hline SALE $=2.35+78.1^{*}$ DUMMY & $\overline{\text { S2 }+6.25^{*} \text { DUMMY S3 - 1.9*DUMMY S4 - 0.55*DUMMY S5 }}$
\end{tabular}

The pattern of seasonal effects for apples case is significant for a very high probability. The overall effect of seasonal factors is very high on sales by periods. It is evidenced by a high $88 \%$ determination coefficient.

Seasonal effects for January-February and March-June are not significant, while are significant for other periods. It is noted that the seasonal effects for September-December are positive and significant.

\subsection{Sale apples Prizren}

For apples sale in Prizren region we have evaluated the following model:

Dependent Variable: SALE

Method: Least Squares

Sample: 13511500

Included observations: 150

\begin{tabular}{lllll}
\hline \hline Variable & Coefficient & Std. Error & t-Statistic & Prob. \\
\hline \hline C & 4.166667 & 2.632868 & 1.582558 & 0.1157 \\
DUMMY S2 & 74.66667 & 3.723437 & 20.05316 & 0.0000 \\
DUMMY S3 & 2.333333 & 3.723437 & 0.626661 & 0.5319 \\
DUMMY S4 & -4.000000 & 3.723437 & -1.074276 & 0.2845 \\
DUMMY S5 & -1.333333 & 3.723437 & -0.358092 & 0.7208 \\
\hline \hline R-squared & 0.819746 & Mean dependent var & 18.50000 \\
Adjusted R-squared & 0.814774 & S.D. dependent var & 33.50724 \\
S.E. of regression & 14.42081 & Akaike info criterion & 8.207987 \\
Sum squared resid & 30154.17 & Schwarz criterion & 8.308341 \\
Log likelihood & -610.5990 & F-statistic & 164.8556 \\
Durbin-Watson stat & 2.391429 & Prob(F-statistic) & 0.000000 \\
\hline \hline
\end{tabular}

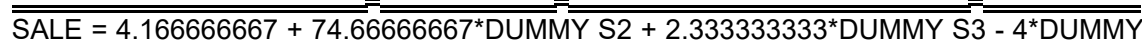
S4 - $1.333333333^{*}$ DUMMY S5 
The pattern of seasonal effects for apples case is significant for a very high probability. The overall effect of seasonal factors is very high on sales by periods; It is evidenced by a high $81 \%$ determination coefficient.

The seasonal effects for January-February and March-June are not significant, while are significant for other periods. It is noted that the seasonal effects for September-October and November-December are positive and significant.

\subsection{The work- occupation of farmers in Korça region in apples activity}

For apples work-occupation in Korça region we have evaluated the following model:

Dependent Variable: Work-occupation

Method: Least Squares

Sample: 1400

Included observations: 400

\begin{tabular}{lllll}
\hline \hline Variable & Coefficient & Std. Error & t-Statistic & Prob. \\
\hline \hline C & 3.070000 & 0.049924 & 61.49324 & 0.0000 \\
DUMMY Work-occup2 & 1.190000 & 0.070603 & 16.85470 & 0.0000 \\
DUMMY Work-occup3 & 1.710000 & 0.070603 & 24.21978 & 0.0000 \\
DUMMY Work-occup4 & 0.040000 & 0.070603 & 0.566544 & 0.5713 \\
\hline \hline R-squared & 0.688437 & Mean dependent var & 3.805000 \\
Adjusted R-squared & 0.686077 & S.D. dependent var & 0.891044 \\
S.E. of regression & 0.499242 & Akaike info criterion & 1.458497 \\
Sum squared resid & 98.70000 & Schwarz criterion & 1.498412 \\
Log likelihood & -287.6995 & F-statistic & 291.6705 \\
Durbin-Watson stat & 2.030987 & Prob(F-statistic) & 0.000000 \\
\hline \hline
\end{tabular}

Work-occupation $=3.07+1.19^{*}$ DUMMY work occup2 $+1.71^{*}$ DUMMY work occup $3+$ $0.04 *$ DUMMY work-occup 4

The model of seasonal effects related to work-occupation of farmers in apples activity for Korça region is significant for a not very high probability. The overall seasonal factors effect of factors is significant over farmers work-occupation by periods; With a determination coefficient by $68 \%$.

The seasonal effects related to farmers' work-occupation in apples activity for Korça region in all periods, April-June, July-September, October-December, are positive and significant.

Based on coefficient values in the periods April-June, July-September, seasonal effects are more significant than in the October to December period, where the respective coefficient in this period is lower, that means seasonal effects are little significant in this period.

\subsection{The work- occupation of farmers in Prizren region on apples activity}

For apples work-occupation in Prizren region we have evaluated the following model:

${ }^{3}$ Dependent Variable: Work-occupation

Method: Least Squares

Sample: 9811200

Included observations: 220

\begin{tabular}{lllll}
\hline \hline Variable & Coefficient & Std. Error & t-Statistic & Prob. \\
\hline \hline C & 2.109091 & 0.143963 & 14.65020 & 0.0000 \\
DUMMY work-occup2 & 2.418182 & 0.203595 & 11.87742 & 0.0000 \\
DUMMY work-occup3 & 2.727273 & 0.203595 & 13.39559 & 0.0000
\end{tabular}

${ }^{3}$ Osmani,M.(2013) Methods of econometrics with EViews 3, Lecture, Agricultural University of Tirana, Albania, Tirana-Albania 2013. 


\begin{tabular}{|c|c|c|c|}
\hline DUMMY work-occup4 & 0.436364 & 0.203595 & 0.0332 \\
\hline${ }^{4}$ R-squared & 0.559535 & Mean dependent var & 3.504545 \\
\hline Adjusted R-squared & 0.553417 & S.D. dependent var & 1.597652 \\
\hline S.E. of regression & 1.067661 & Akaike info criterion & 2.986831 \\
\hline Sum squared resid & 246.2182 & Schwarz criterion & 3.048533 \\
\hline Log likelihood & -324.5514 & F-statistic & 91.46345 \\
\hline Durbin-Watson stat & 1.841569 & Prob(F-statistic) & 0.000000 \\
\hline
\end{tabular}

The model of seasonal effects related to farmers work-occupation in apples activity for the Prizren region is medium significant.

The overall effect of seasonal factors is significant over periods of farmers employment on apples activity; With a determination coefficient of $55 \%$.

Seasonal effects related with farmers' employment in apple activity for Prizren region in all periods, April-June, July-September, October-December, are positive and significant.

Based on the coefficient values in periods April-June, July-September, the seasonal effects are more significant than in the October to December, where the respective coefficients in this period has lower value, which means seasonal effects are little significant in this period.

\subsection{The income of farmers in Prizren region on apples activity}

For apples income in Prizren region we have evaluated the following model:

Dependent Variable: INCOME

Method: ${ }^{5}$ Least Squares

Sample: 1400

Included observations: 400

\begin{tabular}{lllll}
\hline \hline Variable & Coefficient & Std. Error & t-Statistic & Prob. \\
\hline \hline C & 1.000000 & 2.668387 & 0.374758 & 0.7080 \\
DAMIAR2 & 0.450000 & 3.773669 & 0.119247 & 0.9051 \\
DAMIAR3 & 35.20000 & 3.773669 & 9.327791 & 0.0000 \\
DAMIAR4 & 60.35000 & 3.773669 & 15.99239 & 0.0000 \\
\hline \hline R-squared & 0.477555 & Mean dependent var & 25.00000 \\
Adjusted R-squared & 0.473597 & S.D. dependent var & 36.77814 \\
S.E. of regression & 26.68387 & Akaike info criterion & 9.415945 \\
Sum squared resid & 281963.5 & Schwarz criterion & 9.455860 \\
Log likelihood & -1879.189 & F-statistic & 120.6582 \\
Durbin-Watson stat & 2.922623 & Prob(F-statistic) & 0.000000 \\
\hline \hline
\end{tabular}

The seasonal effect model in relation to farmers' income in apple activity for Prizren region is significant for a high probability. The overall effect of seasonal factors is 'nt significant over incomes by periods; With a low coefficient of determination $22 \%$.

The seasonal effects for apples in all periods, April-June, July-September, OctoberDecember, are positive and significant. Based on coefficients values in periods July-September, October-December seasonal effects are more significant than in April-June period, where the respective coefficients in this period are lower. That means that seasonal effects are Little significant in this period compared to other periods.

\footnotetext{
${ }^{4}$ Osmani, M. (2010). Calculation of the general correlation coefficient (pp. 52-54). Tirana, Albania. (2010)

${ }^{5}$ Osmani, M. (2010). The multiple model of regression (pp:49-54). Tirana, Albania, 2010 


\subsection{The price of farmers in Korça region on apples activity}

For apples price in Korça region we have evaluated the following model:

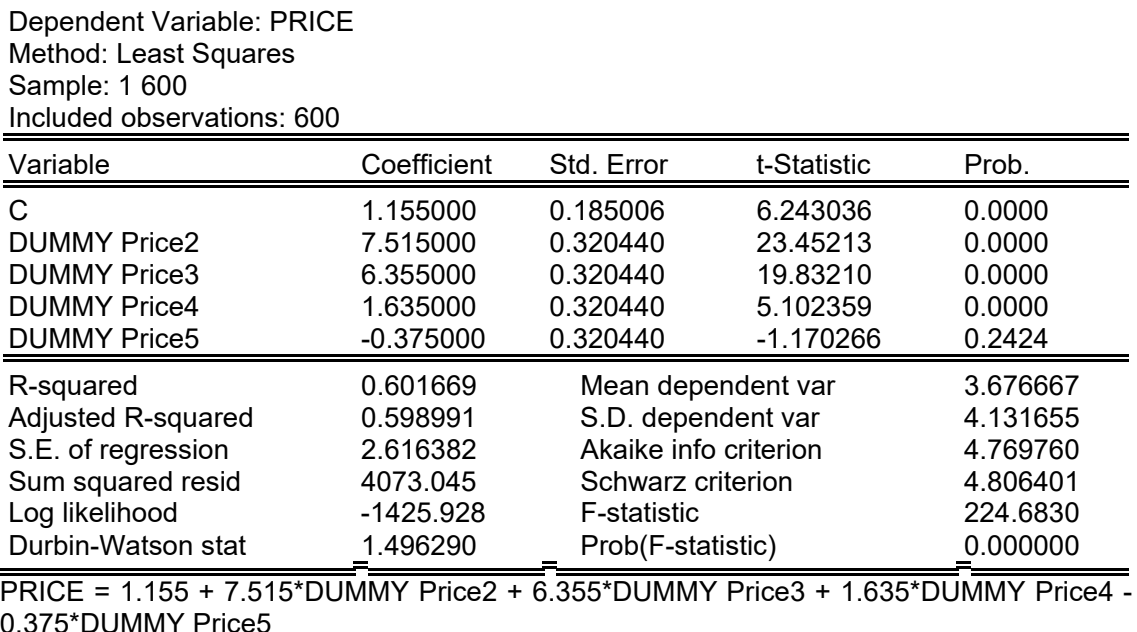

The seasonal effect model in relation to the price of apple for Korça region is significant for a high probability. The overall effect of seasonal factors is significant over the price of apple according to periods; With a determination coefficient of $60 \%$.

Seasonal effects for apples, in September-October, November-December, January-February, based on the coefficient values are positive, that means seasonal effects are significant in these periods. Mainly in September-October and November-December seasonal effects on price of apple are very significant, while for the March-June period the respective coefficients have negative values which means seasonal effects on apple prices are not significant in this period.

\subsection{The price of farmers in Prizren region on apples activity}

For apples price in Prizren region we have evaluated the following model:

Dependent Variable: PRICE

Method: Least Squares

Sample: 16211800

Included observations: 180

\begin{tabular}{|c|c|c|c|c|}
\hline Variable & Coefficient & Std. Error & t-Statistic & Prob. \\
\hline $\begin{array}{l}\text { C } \\
\text { DUMMY Price } 2 \\
\text { DUMMY Price } 3 \\
\text { DUMMY Price } 4 \\
\text { DUMMY Price } 5 \\
\end{array}$ & $\begin{array}{c}0.783333 \\
8.150000 \\
6.016667 \\
1.250000 \\
-0.183333 \\
\end{array}$ & $\begin{array}{l}0.336228 \\
0.582364 \\
0.582364 \\
0.582364 \\
0.582364 \\
\end{array}$ & $\begin{array}{l}2.329769 \\
13.99469 \\
10.33146 \\
2.146425 \\
-0.314809 \\
\end{array}$ & $\begin{array}{l}0.0210 \\
0.0000 \\
0.0000 \\
0.0332 \\
0.7533 \\
\end{array}$ \\
\hline $\begin{array}{l}\text { R-squared } \\
\text { Adjusted R-squared } \\
\text { S.E. of regression } \\
\text { Sum squared resid } \\
\text { Log likelihood } \\
\text { Durbin-Watson stat }\end{array}$ & $\begin{array}{l}0.623565 \\
0.614961 \\
2.604410 \\
1187.017 \\
-425.1707 \\
1.682243\end{array}$ & $\begin{array}{l}\text { Mean d } \\
\text { S.D. de } \\
\text { Akaike } \\
\text { Schwar } \\
\text { F-statist } \\
\text { Prob(F- }\end{array}$ & $\begin{array}{l}\text { lent var } \\
\text { it var } \\
\text { iterion } \\
\text { rion } \\
\text { ic) }\end{array}$ & $\begin{array}{l}3.322222 \\
4.197173 \\
4.779674 \\
4.868367 \\
72.47192 \\
0.000000\end{array}$ \\
\hline
\end{tabular}


The seasonal effect model in relation to the apple price for the Prizren region is significant of a high probability.

The overall effect of seasonal factors is significant over apples price according to periods; With a determination coefficient of $62 \%$.

Seasonal effects for apples, in September-October, November-December, January-February, based on the coefficient values are positive, which means seasonal effects are significant in these periods, mainly in September-October and November-December. The seasonal effects on apples price are very significant, while for March-June period the respective coefficients has negative values which means seasonal effects on apple prices are not significant in this period.

\section{Conclusions and Recommendations}

Concerning the conclusions, in this study, impact of seasonal differences on economic phenomenons taken in the study by quarter was very important for the regions studied in Korça and Prizren.

It is also noted that these seasonal differences in economic phenomena are highly expressed in both regions, slightly more are expressed in the Prizren region.

Through dummy variables we made an estimate of the magnitude of these seasonal differences according to periods studied.

Through variation indicators we show the distribution of the observed phenomenon. Using the coefficient of variation.

By the analysis we saw that the coefficient of variation had generally high values for regions studied, indicating that influence of seasonal effects or external factors is important.

Some of the recommendations for two regions would be to provide more support for farmers by government.

By Investing in setting up protection systems for apple-farms.

It is needed More investment by the government on infrastructure, transportation, warehousing of products etc

\section{References}

Osmani, M. (2010), Calculation of the general correlation coefficient, Vol. II. Tirana, Albania, 2010.

Osmani, M. (2004), Coefficient of variation, Tirana, Albania: GEER,2004.

Osmani, M. (2010) Econometric analysis with dummy variable,Vol. II. Tirana, Albania, 2010.

Osmani, M (2013). Methods of econometrics with Eviews 3 programme.,Lecture, Agricultural University of Tirana, Albania 2013.

Osmani, M.(2010). The multiple model of regression, Vol. II. Tirana, Albania, 2010. 